\title{
Peningkatkan Konsep Diri Positif Peserta Didik di SMP Menggunakan Konseling Individu Rational Emotive Behavior Therapy (REBT)
}

\author{
Andi Thahir, Firdaus \\ Universitas Islam Negeri Raden Intan Lampung \\ Diterima: Juni 2017. Disetujui: Oktober 2017. Dipublikasikan: Desember 2017
}

\begin{abstract}
Positive self concept that arises in the counselee stems from the belief and positive piker pattern of the counselee to the ability and potential that he has. The results showed that the subjects had low selfconcept. Low self-concept is shown include embarrassment with different physical circumstances, minder, do not want to ask the teacher if you do not understand, do not want to go forward, do not want to mingle with friends and, feel different from friends because always called as duck every talking. The purpose of this study is to change the client's irrational beliefs (which impact on emotions and behavior) to be irrational. Rational Emotive Behavior Therapy (REBT) aims to improve and change attitudes, perceptions, beliefs and views of irrational counselees to be rational, so that the counselee can develop themselves and achieve optimal self-realization. The type of research used in this study is a qualitative case study that is descriptive. Observation results show that after being given individual counseling service of Rational Emotive Behavior Therapy (REBT) technique there is a change, that the counselee is no longer embarrassed by his physical condition, going out of class to play, the counselee asks and forward the class, start accepting the shortcomings and try to optimize the potential there on him. The use of individual counseling techniques Rational Emotive Behavior Therapy (REBT) can help students in improving the concept of Positive Self
\end{abstract}

Keywords: REBT, Confidence, Disciplined; Physical

Abstrak: Konsep diri positif yang timbul didalam diri konseli bermula dari keyakinan dan pola piker positif konseli terhadap kemampuan dan potensi yang ia miliki. Hasil penelitian menunjukkan bahwa subyek penelitian memiliki konsep diri yang rendah. Konsep diri yang rendah ditunjukkan meliputi malu dengan keadaan fisik yang berbeda,minder,tidak mau bertanya kepada guru apabila belum mengerti, tidak mau maju kedepan,tidak mau berbaur dengan teman-teman dan, merasa berbeda dengan teman-teman karna selalu dipanggil dengan sebutan bebek setiap berbicara. Tujuan penelitian ini adalah untuk mengubah keyakinan irrasional yang dimiliki klien (yang memberikan dampak pada emosi dan perilaku) menjad irasional. Rational Emotive Behavior Therapy (REBT) bertujuan untuk memperbaiki dan mengubah sikap, persepsi, cara berfikir keyakinan serta pandangan konseli yang irrasional menjadi rasional, sehingga konseli dapat mengembangkan diri dan mencapai realisasi diri yang optimal. Jenis penelitian yang digunakan dalam penelitian ini adalah studi kasus kualitatif yang bersifat descriptif. Hasil Observasi menunjukkan bahwa setelah diberikan layanan konseling individu teknik Rational Emotive Behavior Therapy (REBT) terdapat perubahan, yaitu konseli tidak lagi malu dengan keadaan fisiknya, mau keluar kelas untuk bermain, konseli mau bertanya danmaju kedepan kelas, mulai menerima kekurangannya dan berusaha mengoptimalkan potensi yang ada pada dirinya. Penggunaan konseling individu teknik Rational Emotive Behavior Therapy (REBT) dapat membantu siswa dalam meningkatkan Konsep Diri Positifnya.

Katakunci: REBT,Self; Confidence; Berkelainan; Fisik

\section{Pendahuluan}

Dalam kaitannya dengan perkembangan individu, manusia dapat tumbuh dan berkembang melalui suatu proses alami menuju kedewasaan baik itu bersifat jasmani maupun 
rohani. Oleh sebab itu manusia memerlukan pendidikan demi mendapatkan perkembangan yang optimal sebagai manusia. Selaras yang diungkapkan oleh Prayitno bahwa Bimbingan dan Konseling adalah "Proses pemberian bantuan yang dilakukan oleh orang yang ahli kepada seseorang atau beberapa orang agar orang yang dibimbing dapat mengembangkan kemampuan dirinya sendiri dan mandiri dengan memanfaatkan kekuatan individu dan sarana yang ada dan dapatdikembangkan berdasarkan norma-norma yang berlaku".Layanan Bimbingan dan Konseling yang terdapat disekolah memiliki peranan yang penting dalam mengembangkan diri peserta didik, khususnya konsep diri peserta didik. Di dalam Bimbingan dan Konseling terdapat 4 bidang bimbingan yaitu pribadi, sosial, belajar, dan karier.Bimbingan pribadi-sosial lebih terfokus pada upaya membantu peserta didik untuk mengembangkan aspek-aspek kepribadian yang menyangkut pemahaman diri dan lingkungan, kemampuan memecahkan masalah, konsep diri, kehidupan emosi dan identitas diri. Layanan bimbingan pribadi sangat erat kaitannya dengan membantu peserta didik menguasai tugas-tugas perkembangan sesuai dengan tahapan-tahapannya(Prayitno \& Amti, 2009). Sesuai dengan tujuan layanan Bimbingan dan Konseling yang terkait dengan aspek pribadi-sosial yaitu:

1. Memiliki komitmen yang kuat dalam mengamalkan nilai-nilai keimanan dan ketakwaan kepada Tuhan Yang Maha Esa, baik dalam kehidupan pribadi, keluarga, pergaulan dengan teman sebaya maupun masyarakat pada umumnya

2. Memiliki sikap toleransi terhadap umat beragama lain dengan saling menghormati

3. Memiliki pemahaman tentang irama kehidupan yang bersifat fluktuatif antara yang menyenangkan dan yang tidak menyenangkan (musibah), serta mampu

4. meresponnya secara positif

5. Memiliki pemahaman dan penerimaan diri secara objektif dan konstruktif, baik yang terkait dengan keunggulan maupun kelemahan, baik fisik maupun psikis

6. Memiliki sikap positif atau respek terhadap diri sendiri maupun orang lain

7. Memiliki kemampuan untuk melakukan pilihan secara sehat

8. Menghormati, menghargai orang lain dan tidak melecehkan martabat atau harga dirinya

9. Memiliki rasa tanggung jawab yang diwujudkan dalam bentuk komitmen terhadap tugas atau kewajibannya

10. Memiliki kemampuan untuk mengambil keputusan secara efektif

11. Memiliki kemampuan berinteraksi sosial yang diwujudkan dalam bentuk persahabatan atau persaudaraan(Prayitno \& Amti, 2009).

Sebagai individu, Peserta didik memiliki berbagai potensi yang dapat dikembangkan. Kenyataan yang dihadapi, tidak semua siswa menyadari potensi yang dimiliki untuik kemudian memahami dan mengembangkannya. Menyadari hal diatas peserta didik perlu bantuan dan bimbingan orang lain agar dapat bertindak dengan tepat sesuai dengan potensi yang ada pada dirinya. Sekolah sebagai institusi pendidikan tidak hanya berfungsi memberikan pengetahuan tetapi juga mengembangkan keseluruhan kepribadian Peserta didik. Berikut ini adalah hasil observasi peneliti terhadap subyek penelitian sebelum melakukan konseling individu Rasional Emotif Behaviour terapi. 


\begin{tabular}{llll}
\multicolumn{2}{c}{ Tabel } & 1. Hasil Observasi Konsep Diri Konseli X Kelas IX SMP N 10 & Bandar Lampung \\
\hline No & Aspek Pengamatan & YA & TIDAK \\
\hline 1 & Mempunyai Penerimaan diri yang baik & $\sqrt{ }$ & \\
2 & Minder & $\sqrt{ }$ & \\
3 & Mudah Menyerah & & $\sqrt{ }$ \\
4 & Berani berargumen di kelas & $\sqrt{ }$ \\
5 & Mengenal dirinya dengan baik & $\sqrt{ }$ & $\sqrt{ }$ \\
6 & Mengetahui kelebihan dan kekurangan & & $\sqrt{ }$ \\
7 & Mudah cemas dalam menghadapi berbagai situasi & & $\sqrt{ }$ \\
8 & Menerima dan memberikan pujian dengan wajar & & $\sqrt{ }$ \\
9 & Mau memperbaiki diri kearah yang lebih baik & & \\
10 & Mampu menempatkan diri dengan baik & & \\
\hline
\end{tabular}

Berdasarkan hasil observasi pada peserta didik kelas IX pada tabel1 dapat disimpulkan bahwapeserta didik X sebelum mendapat perlakuan berupalayanan konseling individu teknik Rational Emotive Behavior Therapy(REBT) berada pada kondisi seseorang yangmemiliki konsep diri positif yang rendah. Data pada tabel di peroleh dari dokumentasi buku catatan permasalahan peserta didik oleh guru Bimbingan dan Konseling, informasi dari wali kelas, guru dan laporan dari teman-temannya.peserta didik yang belum memahami bagaimana pengertian dan pentingnya konsep diri positif sesorang dan konseli belum diberikan konseling individu dengan tekhnik Rasional Emotif Behaviour Terapi Menurut Elizabeth B.Hurlock, usia remaja berlangsung dari usia 13-14 tahun sampai 21 tahun.8Masa remaja merupakan salah satu masa dalamn rentang kehidupan yang dilalui oleh individu(Hurlock, 2002).

Masa ini merupakan periode kehidupan yang dalam perkembangan dan merupakan masa transisi menuju pada perkembangan masa dewasa sehat. Masa dewasa yang sehat akan tercapai apabila individu mampu mengentaskan tugas-tugas karena pada dasarnya setiap periode dalam rentang kehidupan individu memiliki tugas perkembangannya masing-masing. Tugas perkembangan merupakan suatu tugas yang muncul pada periode tertentu dalam rentang kehidupan. Tugas-tugas perkembangan berkaitan dengan sikap, perilaku atau keterampilan yang sebaiknya dimiliki oleh individu, sesuai dengan fase atau usia perkembangannya. Pikunas mengemukakan salah satu tugas perkembangan yang penting pada tahap pertengahan dan akhir masa remaja yaitu dapat menerima diri sendiri dan mengandalkan kemampuan dan sumbersumber yang ada pada dirinya sendiri(Syamsu, 2007).

Menurut Erikson, masa remaja adalah masa yang akan melalui krisis dimana remaja berusaha untuk mencari identitas diri (search for self - identity).11Remaja mulai mencari tahu siapa diri mereka, seperti apa watak mereka dan bagaimana orang lain menilai diri mereka. Pembentukan konsep diri pada remaja sangat penting karena akan mempengaruhi kepribadian, tingkah laku dan pemahaman terhadap diri sendiri. Konsep diri merupakan sifat yang unik pada manusia sehingga dapat digunakan untuk membedakan manusia dari makhluk hidup manusia sehingga dapat digunakan untuk membedakan manusia dari makhluk hidup lainnya. William D.Brooks mendefinisikan konsep diri sebagai pandangan dan perasaan kita tentang diri kita, persepsi tentang diri bersifat psikologi, sosial dan fisik(Rakhmat, 2005).

Setiap individu memiliki konsep diri dan dapat berkembang menjadi konsep diri positif maupun negatif, namun demikian individu pada umumnya tidak tahu apakah konsep diri yang 
dimiliki itu negatif atau positif. Individu yang memiliki konsep diri positif akan memiliki dorongan untuk mengenal dan memahami dirinya sendiri.dalam hal ini individu dapat menerima dirinya secara apa adanya dan akan mampu mengenali dirinya melalui kelebihan dan kelemahan yang dimiliki sedangkan individu yang memiliki konsep diri negatif, ia tidak memiliki kestabilan perasaan dan keutuhan diri, tidak mampu mengenal diri sendiri baik kelebihan maupun kelemahan serta potensi yang dimiliki. Individu yang memiliki konsep diri negatif adalah individu yang pesimis, merasa dirinya tidak berharga dan tidak tahan dengan kritikan yang diberikan kepadanya. Konsep diri positif terjadi jika individu tersebut dapat menerima kelebihan dan kekurangannya yang ia miliki, dapat menerima dirinya, setara atau sama dengan orang lain, percaya diri dan mampu menyelesaikan permasalahan yang dihadapi. Seseorang individu yang dapat menyikapi kegagalan kemudian bangkit dan berusaha menyelesaikan masalah adalah individu yang memiliki konsep diri positif. Indikator Konsep Diri Positif menurut Calhaon dan Acocela yaitu:

a. Mempunyai penerimaan diri yang baik b. Mengenal diri sendiri dengan baik

b. Dapat memahami dan menerima fakta-fakta yang nyata tentang dirinya d. Mampu menghargai dirinya sendiri

c. Mampu menerima dan memberikan pujian secara wajar f. Mau memperbaiki diri kearah yang lebih baik

d. Mampu menempatkan diri didalam lingkungan.

Konsep Dasar Konseling Rasional Emotif Behaviour Terapi adalah manusia dilahirkan dengan potensi baik untuk berpikir rasional dan jujur maupun untuk berpikir irasional dan jahat. Manusia memiliki kecenderungan untuk memelihara diri, berbahagia, berpikir dan mengatakan, mencintai, bergabung dengan orang lain serta tumbuh dan mengaktualkan diri, menghindari pemikiran-pemikiran, berlambat- lambat, menyesali kesalahan-kesalahan secara tak berkesudahan, mencela diri serta menghindari pertumbuhan aktualisasi diri.

\section{Metode Penelitian}

Dalam penelitian ini peneliti menggunakan pendeketan kualitatif dengan jenis penelitian case study research (studi kasus) dan bersifat deskriptif. Menurut Denzin dan Lincoln penelitian kualitatif merupakan penelitian yang menggunakan latar alamiah, dengan maksud menafsirkan fenomena yang terjadi dan dilakukan dengan jalan melibatkan berbagai metode yang ada. Pendekatan kualitatif adalah pendekatan yang penting untuk memahami suatu fenomena sosial dan perspektif individu yang diteliti. Pendekatan kualitatif juga merupakan yang mana prosedur penelitiannya menghasilkan data deskriptif yang berupa kata-kata yang secara tertulis ataupun lisan dari prilaku orang-orang yang diamati. Dalam penelitian ini menggunakan jenis penelitian case study research (studi kasus). Menurut Suharsimi Arikunto studi kasus adalah pendekatan yang dilakukan secara intensif, terperindi dan mendalam terhadap gejala-gejala tertentu. Pengertian studi kasus menurut Basuki adalah suatu bentuk penelitian atau studi suatu masalah yang memiliki sifat kekhususan, dapat dilakukan baik dengan pendekatan kualitatif maupun kuantitatif, dengan sasaran perorangan ataupun kelompok, bahkan masyarakat luas.Sedangkan Stake menambahkan bahwa penekanan studi kasus adalah memaksimalkan pemahaman tentang kasus yang dipelajari dan bukan untuk mendapatkan generalisasi, kasusnya dapat bersifat komplek maupun sederhana dan waktu untuk mempelajari dapat pendek atau panjang, tergantung waktu untuk berkonsentrasi(Arikunto, 2010). Design yang digunakan adalah single case design yaitu suatupenelitian studi kasus yang 
menekankan penelitian hanya pada sebuah unit kasus aja. Jadi peneliti berfokus pada satu obyek tertentu yang mempelajarinya sebagai suatu kasus.

rational emotive behavior therapy terbukti efektif meningkatkan self esteem dari kategori rendah (pretest) menjadi kategori sedang (post test) dan tetap bertahan setelah 2 minggu perlakuandan hasil analisis kualitatif menunjukkan bahwa rational emotive behavior therapy akan memberikan hasil yang lebih optimal apabila diberikan kepada subjek yang memiliki kapasitas intelektual rata-rata atas dan aktif selama sesi terapi berlangsung(Hasibuan \& Wulandari, 2015). Pendekatan rational emotive behavior therapy dapat meningkatkan self esteem peserta didik kelas VIII SMP Muhmaadiyah Jati Agung Lampung Selatan memiliki pengaruh, sehingga guru bimbingan konseling agar dapat menggunakan layananan individual melalui pendekatan rational emotive behavior therapy dalam meningkatkan self esteem peserta didik(Ikbal \& Nurjannah, 2016). Penggunaan konseling kelompok REBT juga terbukti efektif dalam meningkatkan self esteem mahasiswa(Sari \& Soejanto, 2016).

Data studi kasus dapat diperoleh dari semua pihak yang bersangkutan, dengan kata lain dalam studi ini dikumpulkan dari beberapa sumber. Dari beberapa macam metode observasi maka dalam penilitian inipeneliti menggunakan observasi non partisipan., peneliti tidak terlibat langsung didalam kehidupan orang yang diobservasi, dan secara terpisah berkedudukan sebagai pengamat, observasi dalam hal ini merupakan pengamatan terstruktur, karena aspek yang diamati dari aktivitas relevan dengan masalah serta tujuan penelitian dengan terlebih dahulu menentukan secara umum prilaku apa yang ingin diamati agar masalah yang dipilih dapat terpecahkan.

\section{Hasil dan Pembahasan}

Aktivitas dan pelaksanaan layanan bimbingan dan konseling di SMP N 10 Bandar Lampung menggunakan pola 17 plus yang menjadi 4 bidang bimbingan, bimbingan pribadi, sosial, belajar dan karir yang dilaksanakan melalui 10 jenis layanan yaitu layanan orientasi, informasi, penempatan, dan penyaluran, penguasaan konten, Bimbingan kelompok, konseling kelompok, konseling individu, konsultasi, mediasi dan layanan advokasi. Ditumjang dengan 6 kegiatan pendukung yaitu, aplikasi instrumen, himpunan data, kunjungan rumah, konferensi kasus, alih tangan kasus, dan tampilan kepustakaan. Layanan BK di SMP N 10 Bandar Lampung bisa dikatakan cukup memadai dan efektif, dengan kendali dari ke-4 guru BK sehingga, pelaksanaan layanan BK berjalan dengan baik. Ditambah lagi selain guru BK yang antusias dalam melaksanakan tugasnya, sarana dan prasana yang juga ikut serta mendukung untuk pelaksanaan layanan BK, memiliki ruang BK sendiri, lengkap dengan ruang guru BK, memiliki ruang BK sendiri, lengkap dengan ruang BK, ruang bimbingan kelompok dan individu (ruang konsultasi ). Layanan layanan BK yang di berikan berjalan dengan baik, disesuaikan dengan kurikulum dan jadwal sesuai dengan tingkatannya.B. Penyajian dan Analisis Data. Proses layanan bimbingan konseling individu yang di berikan guru BK di peroleh dari hasil observasi pada waktu penelitian 12 Oktober 2017 sampai dengan selesai.

Peserta didik yang menjadi subjek penelitian ini adalah peserta didik yang memiliki permasalahan rendahnya konsep diri positif di SMP Negeri 10 Bandar Lampung. Bentuk rendahnya konsep diri positif peserta didik, misalnya tidak mempunyai penerimaan diri yang baik, minder, mudah menyerah, tidak berani beragumen di kelas, tidak mengenal dirinya dengan baik, tidak mengetahui kelebihan dan kekurangannya, mudah cemas dalam menghadapi berbagai situasi, belum bisa menerima dan memberikan pujian secara wajar, belum bisa memperbaiki diri kearah yang lebih baik, belum mampu menempatkan diri dengan baik. Berdasarkan masalah 
yang di alami peserta didik tersebut, maka guru BK disini berperan untuk membantu peserta didik mengatasi permasalahan tersebut.

Berdasarkan wawancara dengan guru BK dan pengamatan di SMP Negeri 10 Bandar Lampung di temukan 1 orang peserta didik yang mengalami permasalahan rendahnya konsep diri positif. Sesuai dengan tujuan penelitian ini yaitu untuk mengetahui keadaan peserta didik sebelum memperoleh layanan konseling individu dengan tekhnik Rasional Emotif Behaviour Terapi. Berikut ini adalah hasil observasi awal pada peserta didik :Tabel 1 Hasil Observasi Konsep Diri Konseli X kelas IX SMP N 10 Bandar Lampung

\begin{tabular}{llll}
\hline No & Aspek Pengamatan & YA & TIDA \\
\hline 1 & Mempunyai Penerimaan diri yang baik & $\sqrt{ }$ \\
2 & Minder & $\sqrt{ }$ & \\
3 & Mudah Menyerah & $\sqrt{ }$ & $\sqrt{ }$ \\
4 & Berani berargumen di kelas & $\sqrt{ }$ \\
5 & Mengenal dirinya dengan baik & $\sqrt{ }$ \\
6 & Mengetahui kelebihan dan kekurangan & $\sqrt{ }$ \\
7 & Mudah cemas dalam menghadapi berbagai situasi & & $\sqrt{ }$ \\
8 & Menerima dan memberikan pujian dengan wajar & & $\sqrt{ }$ \\
9 & Mau memperbaiki diri kearah yang lebih baik & & \\
10 & Mampu menempatkan diri dengan baik & & \\
\hline
\end{tabular}

Berdasarkan hasil observasi pesertan didik X pada tabel 1 dapat di simpulkan bahwa peserta didik X sebelum mendapat layanan konseling individu Rasional Emotif Behaviour Terapi pada kondisi konsep diri positif yang rendah. Sebagaimana yang diungkapkan oleh ibu Apriyana pada saat wawancara beliau mengungkapkan alasan kenapa menggunakan konseling individu dengan teknik Rasional Emotif Behaviour Terapi untuk membantu permasalahan rendahnya konsep diri positif di SMP N 10 Bandar Lampung :

"Layanan yang biasa saya berikan merujuk pada permasalahan peserta didik itu sendiri, selain merujuk pada teori teori konselingnya. maka dari itu sesuai dengan teorinya Albert Ellis bahwa dengan teknik Rasional Emotif Behaviour Terapi dapat merubah pikiran irasional konseli yang menyebabkan konseli memiliki konsep diri rendah menjadi pikiran rasional untuk meningkatkan konsep diri konseli yang rendah, maka saya juga menerapkan hal tersebut di SMP N 10 Bandar Lampung”.

Hal tersebut di buktikan dengan pernyataan konseli $\mathrm{X}$ : “ iya bu, memang benar saya merasa berbeda dengan orang lain, saya selalu sedih dan tidak menerima keadaan saya apalagi kalau saya berbicara saya sering diejek bebek oleh teman-teman saya dengan sebutan bebek. Hal tersebut dibuktikan dengan pernyataan wali kelas :

"ia nak memang benar peserta didik X tumbuh menjadi siswa yang pendiam dan tidak memiliki banyak teman karna dia merasa minder dengan kondisi dirinya yang memiliki bibir sumbing”.

Dalam bab ini akan diuraikan data-data khusus hasil penelitian melalui wawancara dan observasi tentang pelaksanaan bimbingan dan konseling individu dengan tekhnik Rasional Emotif 
Behaviour Terapi untuk mengatasi permasalahan rendahnya konsep diri positif peserta didik di SMP N 10 Bandar Lampung, adapun data yang diperoleh adalah sebagai berikut :

\section{Bagaimana ibu melaksanakan layanan konseling individu Rasional Emotif}

Behaviour Terapi dalam meningkatkan konsep diri positif peserta didik ? Hasil wawancara dengan ibu Apriyana adalah sebagai berikut : "layanan konseling individu dengan teknik REBT yaitu dengan masuk kelas pada saat jam kosong, sedangkan penggunaan konseling individu dengan teknik REBT yaitu dengan memanggil peserta didik keruang konsultasi, setelah itu pada pertemuan awal menyampaikan manfaat dan tujuan dari kegiatan konseling individu. selanjutnya saya menjalankan tahapan teori A-B-C-D-E-F secara bertahap lalu terus mengkonfrontasi pemikiran-pemikiran konseli yang irasional menjadi rasional salah satunya dengan bilbiotherapy dengan menceritakan tokoh yang terkenal yang lebih memilki banyak kekurangan fisik seperti lena maria yang kaki dan tangan yang cacat tetapi ia bisa hidup bahagia dan produktif seperti orang normal ".

Hal senada juga dikemukakan oleh ibu elly yang juga sebagai guru BK SMP N 10 Bandar Lampung :"kami memberikan Layanan konseling individu yang bertujuan untuk layanan bimbingan dan konseling yang memungkinkan peserta didik mendapatkan layanan langsung tatap muka dengan guru pembimbing. Hal ini dilakukan dalam rangka pembahasan dan pengentasan permasalahan pribadi yang di deritanya"

Dari hasil wawancara kepada dua orang guru BK, dapat disimpulkan bahwa dalam pelaksanaan konseling REBT dilakukan dengan konseling individu, dengan materi yang disampaikan disesuaikan dengan kebutuhan peserta didik. Dengan tujuan agar konseli X mampu mengubah keyakinan irasionalnya menjadi rasional sehingga peserta didik dapat meningkatkan konsep diri positif dirinya menjadi lebih bahagia dan produktif.

2. Mengapa ibu menggunakan konseling individu dengan teknik REBT untuk meningkatkan konsep diri positif peseta didik $\mathrm{X}$ ?

Hasil wawancara dengan guru BK, peserta didik, dan wali kelas, guru BK menyatakan alasannya sebagai berikut :"alasan saya menggunakan konseling individu dengan teknik REBT, atas dasar berlandaskan pada latar belakang masalah yang dihadapi konseli yang menunjukkan ciri-ciri seseorang yang memiliki konsep diri positif rendah yang disebabkan oleh pikiran irasionalnya sehingga digunakanlah teknik konseling individu REBT untuk merubah pikiran irasional peserta didik menjadi rasional sehingga peserta didik dapat meningkatkan konsep diri positif peserta didik yang bersumber dari pikiran rasionalnya.

Pernyataan tersebut diperkuat dengan pernyataan konseli X :

" saya merasa berbeda dengan teman-teman saya pak, saya selalu diejek bebek jika saya berbicara, maka dari itu saya jarang berbicara, saya juga tidak punya teman dan saya merasa tidak ada yang mau berteman dengan saya"

Hal yang senada juga dikemukakan oleh ibu rafika selaku wali kelas IX i terkait layanan bimbingan konseling yang diberikan guru BK : 
"selama saya mengajar disini, menurut saya cukup baik, layanan yang diberikan oleh guru BK, untuk mengatasi permasalahan peserta didik, terutama permasalahan konsep diri positif rendah tersebut, guru BK juga cukup aktif, dengan melakukan konseling dan mendata peserta didik yang bermasalah". 8

Dari hasil wawancara dapat disimpulkan bahwa alasan guru BK melaksanakan konseling individu dengan teknik REBT untuk meningkatkan konsep diri positif peserta didik itu tepat karna sesuai untuk mengubah pola pikir peserta didik yang irasional menjadi rasional dimana pemikiran irasional berdampak pada konsep diri positif peserta didik menjadi rendah

3. Bagaimana tahap-tahap yang dilakukan dalam pelaksanaan konseling individu dengan teknik REBT?

Hasil wawancara : Hasil wawancara kepada ibu Apriyana dan konseli X :

"sebelum saya melakukan kegiatan dan layanan saya menyiapkan tempat dan perlengkapan yang akan digunakan. Setelahnya semuanya siap, kemudian saya menemui konseli X untuk melakukan konseling, proses atau tahap-tahap yang saya lakukan dalam pelaksanaan konseling individu ada 3 tahap, pertama tahap awal (mengidentifikasi masalah), tahap inti (tahap kerja), tahap akhir (tahap perubahan

dan tindakan)".

Hal yang diungkapkan oleh konseli X sebagai bukti pelaksanaan layanan yang diberikan :

"tahapan yang diberikan ibu yana dalam pelaksanaan konseling individu pertama saya diberikan maksud dan tujuan kegiatan, saya melakukan kontrak kegiatan dan menceritakan masalah saya, kemudian menceritakan masalah saya secara lebih jelas, dan saya disuruh menyimpulkan apa nanti yang akan saya buat untuk perubahan diri saya, saya yang membuat dan saya yang melakukan".

Dari hasil wawancara yang peneliti lakukan, dapat disimpulkan bahwa dalam pelaksanaan konseling individu dengan teknik REBT dilakukan melalui 3 tahapan yaitu, tahap awal, tahap inti, dan tahap akhir.

4. Bagaimana langkah yang di lakukan dalam melakukan Konseling individu menggunakan teknik REBT ?

Hasil wawancara : peneliti melakukan wawancara kepada guru BK yaitu ibu yurdianigsih dan konseli X : 
"Langkah pertama adalah menunjukkan kepada konseli bahwa dirinya tidak logis, membantu mereka memahami bagaimana dan mengapa menjadi demikian dan menunjukkan hubungan gangguan yang irasional lalu langkah ke dua yaitu membantu konseli meyakini bahwa berfikir tidak logis dapat ditantang dan diubah. Kesediaan konseli untuk dieksplorasi secara logis terhadap gagasan yang dialami oleh konseli dan konselor mengarahkan pada konseli untuk melakukan disputing terhadap keyakinan konseli yang irasional. Tahap ketiga yaitu melakukan kontrak konseling lalu merubah pemikirannya yang irasional lalu mencoba bersikap rasional dalam menghadapi masalah. Pernyataan tersebut diperkuat dengan pernyataan peserta didik yaitu :

"saya pernah di panggil guru BK waktu istirahat saya di tanya-tanya kenapa saya tidak main sama temen-temen saya ceritakan saja pak, karna saya minder dengan temen-temen sering diejek bebek karna suara saya sumbang”.

Dari hasil wawancara yang dilakukan peneliti, dapat disimpulkan bahwa dalam konseling individu REBT diminta untuk mengungkapkan permasalahannya, sebab akibat kenapa konseli X tidak bisa menerima dirinya dan diberikan kontrak konseling untuk mencoba merubah pemikiran irasionalnya dan mulai mencoba bersikap rasional sesuai dengan kontrak konseling yang dilakukan.

5. Langkah apa yang dilakukan setelah Konseli $\mathrm{X}$ diminta untuk mengungkapkan masalah ?

Hasil wawancara : Hasil wawancara yang dikemukakan oleh guru BK sebagai berikut

"Pada pertemuan kali ini diharapkan konseli mampu menerapkan cara berpikir logis dan emnpiris dalam menyikapi setiap masalah yang di hadapinya. Oleh karena itu pada awal-awal pertemuan saya kembali mengevaluasi pertemuan sebelumnya bersama dengan konseli. saya mengajarkan cara berpikir logis dan empiris ini dengan membandingkan dengan orangorang yang kurang beruntung melebihi konseli permasalahannya seperti cacat fisik yang tidak memiliki kaki atau tangan tetapi dia bisa produktif dan sukses agar dapat mengambil sisi positif dari permasalahan tersebut, dalam proses pengarahan konseli disini peneliti memberikan teknik bibliotherapy yang berupa memberikan pemahaman terhadap konseli seperti kisah nyata lena Maria. Sehingga konseli dapat mengubah persepsinya yang irasional menjadi rasional mengenai dirinya sendiri. Selain itu konseli di ajak untuk mencoba bergaul dengan temantemannya,mengajarkan konseli untuk berlatih baagaimana berbicara seperti bertanya jika ada pelajaran yang kurang dipahami lalu belajar menjawab pertanyaan-pertanyaan pelajaran yang saya ajukan, pertama

didepan saya lalu mempraktekkannya di kelas”.

Berdasarkan hasil wawancara dapat disimpulkan bahwa dalam konseling individu REBT guru BK menceritakan kisah inspriratif yang permasalahannya sama dengan konseli lalu merubah pikiran irasional konseli secara bertahap dan melatih konseli untuk bersikap produktif dan rasional secara terus menerus dan mempraktekannya di kehidupan konseli terutama di sekolah.

6. Langkah apa yang dilakukan setelah melakukan Konseling REBT?

Hasil wawancara : wawancara yang dikemukakan oleh guru BK : 
"selanjutnya saya membimbing konseli X yaitu menjelaskan kepada konseli harapan-harapan konseling, tujuannya, untuk bisa merubah dirinya. adapun tujuan proses konseling ini adalah konseli X mampu menerima dirinya, sesuai dengan kemampuannya seperti bergaul dengan teman-temannya, belajar beragumen dikelas dan tidak minder dengan keadaan yang ia alami sehingga

ia tidak merasa tertekan didalam dirinya".

Pernyataan tersebut diperkuat dengan pernyataan konseli X :

"saya sudah berjanji dengan bu Yana bahwasanya, saya akan belajar dan berusaha untuk dapat menerima diri saya dan mencoba melakukan kontrak konseling yang sudah saya buat yaitu berani berargumen di kelas, walaupun saya agak malu dan grogi tapi saya akan selalu mencoba dan saya berusaha menanamkan rasa percaya diri pada diri saya ".

7. Apakah konseling individu dengan teknik REBT diminati oleh peserta didik?

Hasil wawancara: Berikut hasil wawancara yang dilakukan oleh ibu Apriyana, sebagai berikut :

"iya tentu saja diminati, oleh konseli X, karena dengan diberikannya layanan konseling individu dengan teknik REBT peserta didik mampu menyadari dirinya, dan mampu menerima dirinya dan secara bertahap merubah pikiran dan sikap konseli menjadi rasional dan produktif”.

Hal yang serupa diungkapkan oleh wali kelas X, sebagai berikut :

"saya sering melihat $\mathrm{X}$ di panggil ke ruang BK pada waktu istirahat, dan juga saya melihat perubahan pada diri konseli $\mathrm{X}$ seperti, mulai bergaul dengan teman-temannya mulai beragumen di kelas walau masih grogi dan terbata- bata, saya ikut senang dengan perubahan $\mathrm{X}$ walau tidak signifikan". 17

Hal serupa dibuktikan dengan pernyataan konseli X sebagai berikut :

"saya merasa senang dan saya sangat terbantu untuk mengikuti konseling dengan bu Yana, disini saya sadar bahwasanya saya ini harus bisa menerima diri saya dan mulai berani dan percaya diri kalau berbicara dan saya jadi semangat untuk sekolah dan bermain dengan temanteman".

Dari hasil wawancara dapat diketahui dan dilihat bahwa layanan konseling individu dengan teknik REBT sangat diminati oleh konseli $X$, konseli $X$ sangat senang mengikuti layanan tersebut, selain konseli $\mathrm{X}$ yang lebih aktif, konseli $\mathrm{X}$ juga mampu memahami dirinya dan mampu berpikir rasional dan bersikap produktif.

8. Selama melaksanakan layanan hambatan atau kendala apa saja yang dialami dalam pelaksanaan layanan konseling individu dengan teknik REBT ?

Hasil wawancara: berikut hasil wawancara dengan ibu Apriyana, yaitu sebagai berikut :

"alhamdulilah jika berbicara kendala dalam pelaksanaan layanan yang kami hadapi adalah, masalah yang biasa muncul yaitu tidak bisa merubah konseli secara signifikan karna pendekatan 
yang menekankan pada perubahan pikiran bukanlah cara yang paling sederhana dalam membantu peserta didik mengubah pikiran dan perilakunya".

Hal senada diungkapkan oleh ibu Rafika selaku wali kelas peserta didik X :

"saya melihat perubahan pada diri $\mathrm{X}$ walau tidak signifikan seperti dia mulai bergaul dengan teman-temannya dan dia sering bertargumen di kelas, lebih dari hasil wawancara yang peneliti lakukan, terhadap guru BK dan wali kelas, dapat disimpulkan bahwa yang menjadi faktor penghambat dalam pelaksanaan layanan bimbingan konseling individu menggunakan teknik REBT yaitu perubahan pada diri X tidak bisa secara signifikan karna membutuhkan proses dan waktu dalam membimbing peserta didik untuk merubah sifat dan prilakunya ini bukanlah sesuatu yang mudah.

Sebagai bidang yang memiliki fokus dalam pencegahan masalah ataupun, pengentasan masalah yang dialami oleh peserta didik, ternyata bimbingan konseling memiliki media maupun mitra layanan yang termasuk dalam peraaturan menteri pendidikan dan kebudayaan indonesia nomor 111 tahun 2014 tentang bimbingan dan konseling pada pendidikan dasar dan menengah, sebagai upaya memaksimalkan dalam memberikan layanan bimbingan konseling yang membantu dalam proses pengentasan masalah pada peserta didik. Kemudian dalam prakteknya konselor sekolah menggunakan layanan konseling individu dengan pendekatan feminisme dalam layanan bimbingan konseling. Berdasarkan pengamatan, peneliti melihat guru BK sekolah memberikan konseling individu kepada konseli X dengan baik. Peneliti melihat Guru BK sekolah bekerjasama dengan wali kelas dan guru mata pelajaran juga.

Guru BK memberikan konseling individu dengan teknik REBT langsung terhadap konseli $\mathrm{X}$ dan peneliti mengamati layanan konseling individu menggunakan teknik REBT untuk meningkatkan konsep diri positif yang dilaksanakan cukup baik, dilihat dari tahapan yang diberikan, mulai dari tahap perencanaan, pelaksanaan dan evaluasi. Konseling individu teknik REBT diberikan terhadap peserta didik yang mengalami konsep diri positif yang rendah, konseli $\mathrm{X}$ diharapkan mampu meningkatkan konsep diri positifnya. Hal tersebut terbukti dengan ditunjukan konseli $\mathrm{X}$ yang sangat baik dalam mengikuti proses layanan, dengan hasil wawancara peneliti terhadap konseli $\mathrm{X}$ yang selesai melakukan sesi konseling :

"saya sangat senang sekali dengan mengikuti kegiatan ini, perasaan saya sangat lega sudah menceritakan permasalahan saya dan dibantu dalam mencari solusinya, saya tidak kaku dan malu, karna bu apriyana orangnya ramah dan baik, jadi saya merasa nyaman dan lega ketika saya punya masalah saya curhat dengan bu yana sebagai guru BK disini”.

Berdasarkan hasil wawancara, konseli X merasa terbantu dengan diberikannya konseling individu dengan teknik REBT tersebut. Konseli $\mathrm{X}$ mampu meningkatkan konsep diri positifnya dan konseli merasa nyaman melakukan konseling dengan guru BK . Terbukti ketika peneliti melakukan wawancara terhadap konseli $\mathrm{X}$ yang mengikuti kegiatan konseling individu sebagai berikut :

"saya merasa terbantu dan bisa menerima diri saya,sekarang saya punya banyak teman,aktif di kelas, punya rasa percaya diri, saya sangat senang dengan perubahan saya, dan saya tidak ragu lagi kalau punya permasalahan tentang konsep diri, saya akan melakukan konseling lagi dengan bu Yana".22

Berdasarkan wawancara dan observasi hasil penelitian menunjukan bahwa setelah dilakukan konseling individu dengan teknik REBT diperoleh hasil yang cukup memuaskan untuk meningkatkan konsep diri konseli. 
Adapun rendahnya konsep diri yang dialami oleh konseli diakibatkan oleh konseli yang malu akan fisiknya yang berbeda dengan teman- temannya, merasa berbeda dengan temannya,tidak banyak bicara karna malu dengan suaranya yang sumbang dan diejek bebek oleh teman-temannya dengan adanya ejekan-ejekan dari teman-temannya yang membuat konseli tidak mau keluar kelas dan berbaur dengan teman-temannya, setelah itu takut salah apabila bertanya atau menjawab akan membuat guru marah kepada konseli.

Perencanaan Konseling Individu Dengan Teknik Rasional Emotif Behaviour Terapi Untuk Meningkatkan Konsep Diri Positif

Adapun perencanaan yang dilakukan guru BK untuk melaksanakan proses konseling disesuakin dengan Langkah-langkah dalam konseling individual yaitu sebagai berikut:

a. Persiapan, meliputi: kesiapan fisik dan psikis konselor, tempat dan lingkungan sekitar, perlengkapan, pemahaman klien dan waktu.

b. Rapport, yaitu menjalin hubungan pribadi yang baik antara konselor dan klien sejak permulaan, proses, sampai konseling berakhir, yang ditandai dengan adanya rasa aman, bebas, hangat, saling percaya dan

c. saling menghargai.

d. Pendekatan masalah, dimana konselor memberikan motivasi kepada klien agar bersedia menceritakan persolan yang dihadapi dengan bebas dan terbuka.

e. Pengungkapan, dimana konselor mengadakan pengungkapan untuk mendapatkan kejelasan tentang inti masalah klien dengan mendalam dan mengadakan kesepakatan bersama dalam menentukan masalah inti dan masalah sampingan. Sehingga klien dapat memahami dirinya dan mengadakan perubahan atas sikapnya.

f. Diagnostik, adalah langkah untuk menetapkan latar belakang atau factor penyebab masalah yang dihadapi klien.

g. Prognosa, adalah langkah dimana konselor dan klien menyusun rencana-rencana pemberian bantuan atau pemecahan masalah yang dihadapi klien.

h. Treatment, merupakan realisasi dari dari langkah prognosa. Atas dasar kesepakatan antara konselor dengan klien dalam menangani masalah yang dihadapi, klien melaksanakan suatu tindakan untuk mengatasi masalah tersebut, dan konselor memberikan motivasi agar klien dapat mengembangkan dirinya secara optimal sesuaikemampuan yang dimilikinya.

Evaluasi dan tindak lanjut, langkah untuk mengetahui keberhasilan dan efektifitas konseling yang telah diberikan. Berdasarkan hasil yang telah dicapai oleh klien, selanjutnya konselor menentukan tindak lanjut secara lebih tepat, yang dapat berupa meneruskan suatu cara yang sedang ditempuh karena telah cocok maupun perlu dengan cara lain yang diperkirakan lebih tepat. sebelum di lakukannya proses konseling, peneliti juga akan melakukan observasi awal untuk memperoleh data sebelumn dan sesudah di lakukannya proses konseling, yang nantinya akan dibantu oleh tim penilai yang telah dipersiapkan oleh pihak sekolah.

Pelaksanaan Konseling Individu Dengan Teknik REBT Untuk Meningkatkan Konsep Diri Positif Peserta Didik

Pada proses konseling ini akan di gambarkan secara singkat pertemuan guru BK dengan konseli.

Nama : X Kelas :IX i 
Waktu dan tempat : disesuaikan dengan pembelajaran dan persetujuan dari konseli. Adapun pelaksanaan yang dilakukan guru BK untuk melaksanakan proses konseling disesuaikan perencanaan dalam konseling individual yaitu sebagai berikut

1. Observasi awal

Pada kegiatan Observasi awal yang dilakukan guru BK adalah melakukan wawancara tehadap wali kelas siswa $\mathrm{X}$ untuk mendapatkan

informasi yang lebih mendalam kemudian guru BK melakukan observasi yang dibantu oleh tim penilai yang telah di persiapkan oleh pihak sekolah untuk mengisi lembar observasi mengenai Konsep diri positif siswa $\mathrm{X}$ yang dibantu oleh wali kelas untuk menerapkan indikator yang telah ditetapkan di lembar observasi.

\section{Persiapan}

Pada tahap ini guru BK meminta waktu kepada wali kelas saat jam istirahat pertama untuk melakukan pendekatan terhadap peserta didik X yang berada di dalam kelas, serta untuk melihat kesiapan kondisi peserta didik untuk nantinya dapat menerima proses konseling.

\section{Rapport}

Tahap ini adalah tahap awal sebelum memulai konseling. Pada tahapan ini guru BK membina hubungan baik dengan mengawali komunikasi kepada konsel. Tahap ini merupakan tahap yang sangat penting, karena akan mengawali dari proses konseling selanjutnya. Oleh karena itu guru BK membuka dengan pertanyaan netral seperti, bagaimana kondisi kesehatan konseli saat ini, dan seterusnya.

Selanjutnya guru BK berupaya agar subyek dapat lebih terbuka dalam mengutarakan apa yang ia rasakan. Setelah subyek mulai terbuka maka pada pertemuan ini diupayakan agar subyek mau mengungkapkan segala keluhan atas permasalahannya yaitu konsep diri yang ada pada diri konseli X.

\section{Pendekatan masalah}

Tahap ini setelah konseli mulai terbuka dan mulai memberikan informasi permasalahan yan di alami, guru BK mengungkapkan kembali dengan seksama dan jelas permasalah apa yang di alami oleh konseli, sehingga guru BK dapat mulai mengidentifikasi masalah apa yang dihadapi oleh konseli. Sebelumnya, guru BK terlebih dahulu menanyakan kondisi konseli hari ini, bagaimana pembelajarannya, dan sudah siapkah untuk mengungkapkan masalahnya. Lalu guru BK memberikan pemahaman mengenai Bimbingan dan Konseling dan mengajak peserta didik agar benar- benar dapat menerima guru BK sebagai sahabat guru sehingga permasalahan yang dialami peserta didik tidak ada yang di tutup-tutupi.

\section{Pengungkapan}

Setelah dilakukannya pendekatan masalah, konseli X memberikan penjelasan bahwa konseli $\mathrm{x}$ merasakan malu, konseli X merasa dirinya berbeda dengan teman-teman yang lain karna fisik dan suaranya berbeda sehingga konseli merasa tertekan dan tidak aktif sebagai peserta didik, kemudian guru BK memberikan pemahaman tentang penerimaan diri sesuai dengan teori yang ada. 


\section{Diagnostik}

Pada konseling ini guru BK mengajak konseli bersama-sama menelaah permasalahan yang di hadapi konseli kedalam teori, agar di ketahui penyebab timbulnya permasalahan.Pada konseling ini peneliti mengajak konseli bersama-sama menelaah permasalahan yang sedang dihadapai konseli kedalam teori $\mathrm{ABC}$ agar diketahui penyebab timbulnya permasalahan. Adapun permasalahan peserta didik X yaitu, A (activating event) atau perilaku yang mengawali, dimana konseli merasakan malu terhadap fisiknya yang berbeda dan minder kepada teman-temannya dan ia takut merasa takut dimarahi oleh guru apabila menjawab salah. Lalu B (Belief) yaitu keyakinan, pandangan, nilai, atau verbalisasi diri individu terhadap suatu peristiwa, dimana konseli meyakini bahwa dengan menjawab pertnyaan yang salah dapat membuat guru menjadi marah dengannya dan konseli ditertawakan oleh temna-teman sekelasnya. Setelah itu C (C (consequency) yang berupa C-perilaku. Dimana perilaku yang ditunjukkan X yaitu ia hanya diam di kelas saat jam istirahat, banyak menunduk apabila guru memberikan kesempatan kepada konseli untuk menjawab pertanyaan,kurang berbaur dengan teman temannya karna merasa minder dengan keadaanya yang sering diejek dengan sebutan bebek oleh temantemannya.

Tabel 2 Teori ABC Konsep Diri Konseli X Kelas IX SMP N 10 Bandar Lampung

\begin{tabular}{ll}
\hline \multicolumn{2}{l}{ Penerapan Teori ABC dalam REBT pada Konseli } \\
\hline $\mathrm{A} \quad$ (Activating & Malu, minder, takut salah. \\
\hline Bir $\quad$ (Believe & $\begin{array}{l}\text { Jika berbicara ditertawakan karna suaranya } \\
\text { Irrational) }\end{array}$ \\
$\begin{array}{l}\text { mirip bebek, diejek-ejek oleh teman-teman yang lain dengan fisik yang } \\
\text { berbeda. Setelah itu takut jika menjawab atau } \\
\text { bertanya kepada guru maka akan dimarahi dan ditertawakan oleh teman- } \\
\text { teman dikelas dan merasa tak ada yang ingin berteman dengannya }\end{array}$
\end{tabular}

\begin{tabular}{ll}
\hline $\mathrm{C}$ (Consequence $)$ & $\begin{array}{l}\mathrm{C} \text { pada emosi }= \\
\text { murung dan tidak } \\
\text { bahagia }\end{array}$ \\
& $\begin{array}{l}\text { C pada prilaku = takut keluar kelas, tidak aktif di kelas dan tidak berbaur } \\
\text { dengan teman-teman }\end{array}$
\end{tabular}

\section{Prognosa}

Pada pertemuan kali ini diharapkan konseli mampu menerapkan cara berpikir logis dan empiris dalam menyikapi setiap masalah yang dihadapinya. Oleh karena itu pada awal-awal pertemuan peneliti kembali mengevaluasi pertemuan sebelumnya bersama dengan konseli. Peneliti mengajarkan cara berpikir logis dan empiris ini dengan membandingkan pada contoh orang- orang yang sukses walau mereka memiliki keterbatasan fisik seperti Lena Maria atau orang terkenal 
dengan maksud agar konseli dapat mengambil sisi positif dari masalah yang dihadapi orangorang tersebut.

Dalam proses pengarahan konseli disini peneliti memberikan teknik self modeling yang berupa memberikan pemahaman terhadap konseli seperti kisah nyata lena maria yang memiliki kelainan fisik yang tidak memiliki tangan namun bisa menjadi seorang atlet renang dan memiliki kehidupan layaknya orang normal, sehingga konseli dapat mengubah pesepsinya yang irasional menjadi rasional mengenai dirinya sendiri. Selain konseli di ajak untuk melihat teman-teman di sekitarnya bagaimana sikap dan perilaku mereka jika maju kedepan kelas dan respon yang ditunjukkan saat teman- temannya maju kedepan kelas atau menjawab pertanyaan yang diberikan oleh guru agar dapat diterapkan konseli pada dirinya.kemudian dengan teknik social modeling peneliti mengarahkan konseli agar melakukan sikap dan perilaku sesuai yang konseli perhatikan pada self modeling.

\section{Treatment}

Selanjutnya peneliti membimbing konseli untuk mengungkapkan apa yang menjadi harapan atau tujuan dari konseli dalam mengikuti kegiatan konseling kali ini. Adapun yang menjadi tujuan konseling yang diharapkan oleh konseli adalah peserta didik menginginkan berani untuk bersosialisasi diluar kelas, maju kedepan kelas, berani bertanya kepada guru, berani untuk mejawab pertanyaan, tidak minder lagi dan malu dengan kondisi fisiknya yang berbeda. Adapun tindakan yang direncanakan oleh konseli untuk bersosialisasi dan berani keluar kelas yaitu dengan konseli mencoba untk muembuka diri terhadap temantemannya, tidak memasukkan ke dalam hati mengenai ejekan teman-temannya. Setelah itu rencana tindakan untuk konseli berani maju kedepan kelas, berani untuk bertanya apabila ada yang belum dimengerti dan menjawab pertanyaan yang diberikan oleh guru yaitu dengan cara konseli akan belajar dengan giat dan berusaha agar tidak salah sehingga tidak ditertawakan, lalu konseli akan mencoba memberanikan diri maju kedepan kelas.

9. Evaluasi dan tindak lanjut

Tahap ini merupakan tahap terakhir proses konseling. Sebelum memulai konseling peneliti menanyakan kabar konseli terlebih dahulu, menanyakan bagaimana pelajarannya tadi. Memasuki kegiatan konseling peneliti mengevaluasi kegiatan sebelumnya yang sudah dilakukan konseli apakah sudah membawa perubahan yang lebih baik pada diri konseli. Setelah mendengar pemaparan konseli bahwa sudah banyak perilaku konseli yang berubah, peneliti mengajak konseli bersama-sama mendiskusikan keyakinan- keyakinan irasional yang ada. Untuk kegiatan selanjutnya peneliti mengevaluasi kegiatan dari awal sampai akhir konseling dan tujuan-tujuan yang telah dicapai oleh konseli. Kemudian peneliti bersama-sama konseli mengevaluasi hasil pertemuan selama proses konseling dengan menanyakan pemahaman lalu perasaan yang dirasakan dan tindakan. Berikut ini dapat dilihat hasil evaluasi : 
Tabel 3 Hasil Evaluasi Konseli X

\begin{tabular}{ll}
\hline Aspek penilaian & Hasil \\
\hline Pemahaman & $\begin{array}{l}\text { Konseli memahami bahwa akar dari } \\
\text { semua permasalahannya adalah pemikiran irasional dan itu harus dirubah }\end{array}$ \\
\hline $\begin{array}{l}\text { Perasaan } \\
\text { (Comfort) }\end{array}$ & $\begin{array}{l}\text { Konseli merasa senang dan nyaman karena konseling } \\
\text { ini dapat membuatnya mengerti tentang Konsep diri }\end{array}$ \\
\hline Tindakan & $\begin{array}{l}\text { Konseli akan berusaha belajar dengan giat agar } \\
\text { jawaban yang konseli peroleh tidak salah sehingga konseli tidak ditetawakan } \\
\text { oleh teman-temannya. }\end{array}$ \\
& $\begin{array}{l}\text { Mencoba untuk bertanya dan maju kedepan kelas, dan menutupi rasa gerogi } \\
\text { serta minder dengan cara tersenyum. }\end{array}$ \\
& $\begin{array}{l}\text { Lalu konseli akan menjaga pemikirannya agar tetap rasional terhadap } \\
\text { keadaan fisiknya , terus mencoba bergaul dengan teman- temannya, menjalin } \\
\text { komunikasi dengan baik. }\end{array}$ \\
\hline
\end{tabular}

10. Observasi Akhir

Setelah dilakukan evaluasi maka dilakukan kembali observasi dengan dibantu oleh tim penilai yang telah disiapkan oleh pihak sekolah untuk memberikan penilaian sebelum dan sesudah dilakukannya proses konseling dan dibantu oleh ibu wali kelas yang menerapkan indikatorindikator yang ada di lembar observasi, adapun hasilnya yaitu :

Tabel 4 Hasil Observasi Konsep Diri Konseli X kelas IX SMP N 10 Bandar Lampung

\begin{tabular}{lll}
\hline Aspek Pengamatan & YA & TIDAK \\
\hline Mempunyai Penerimaan diri yang baik & $\sqrt{ }$ & \\
Minder & & $\sqrt{ }$ \\
Mudah Menyerah & $\sqrt{ }$ & \\
Berani berargumen di kelas & $\sqrt{ }$ \\
Mengenal dirinya dengan baik & $\sqrt{ }$ \\
Mengetahui kelebihan dan kekurangan & \\
\hline
\end{tabular}




\begin{tabular}{lll}
\hline Mudah cemas dalam menghadapi berbagai situasi & & $\sqrt{ }$ \\
Menerima dan memberikan pujian dengan wajar & $\sqrt{ }$ & \\
Mau memperbaiki diri kearah yang lebih baik & $\sqrt{ }$ & \\
Mampu menempatkan diri dengan baik & $\sqrt{ }$ & \\
\hline
\end{tabular}

Dengan kata lain, permasalahan konsep diri negatif dapat diatasi dengan konseling individu menggunakan teknik REBT, hal ini ditunjukan dengan perubahan perilaku dan pola pikir konseli. Hal tersebut diungkapkan oleh konseli $\mathrm{X}$ dengan pernyataan sebagai berikut :

"setelah saya mengikuti kegiatan konseling, saya menjadi yakin danpercaya bahwa saya ini tidak berbeda dengan teman-teman saya, saya harus lebih percaya diri dengan kekurangan saya karna saya yakin saya punya banyak potensi yang ada pada diri saya, saya pun bisa sukses walau banyak kekurangan dalam diri saya". Dari pernyataan yang diungkapkan peserta didik, peneliti dapat menyimpulkan bahwa penggunaan konseling individu dengan teknik RasionalEmotif Behaviour Terapi untuk meningkatkan konsep diri positif peserta didik berjalan dengan baik.

\section{Simpulan dan Saran}

Berdasarkan hasil analisis pada bab sebelumnya, maka pada bab ini akan disimpulkan hasil penelitian ini. konseling individu dilakukan dengan teknik REBT kepada konseli X menunjukkan bahwa adanya peningkatan konsep diri positif terhadap konseli X. Hal ini ditunjukkan pada pertemuan pertama peneliti memperkenalkan diri di kelas IX bersama wali kelas dan guru BK dari pihak sekolah sekaligus untuk memperoleh data awal permasalah yang dialami oleh konseli dengan menggunakan lembar observasi. Pada pertemuan ke dua peneliti melakukan sesi konseling satu, peneliti memulai membina hubungan yang baik agar konseli lebih terbuka, dan konseli mengakui tidak mau keluar kelas dikarenakan malu dan minder. Pada pertemuan ketiga sesi konseling dua, peneliti mulai mendapatkan informasi mengenai masalah konseli yang berupa konseli malu akan keadaan fisiknya yang membuat konseli malu dan takut diejek apabila keluar kelas. Pemahaman diberikan mengenai konsep diri terhadap konseli sampai konseli benar-benar memahami mengenai konsep diri. Pada pertemuan ke empat sesi konseling tiga, peneliti meberikan pemahaman kepada konseli dengan menginovasikan teknik self modeling untuk membantu merasionalkan pemikiran konseli. Pada pertemuan ke lima (sesi konseling Empat), Konseli yang memiliki masalah konsep diri rendah kini sudah mengalami peningkatan, konseli X sudah mau maju kedepan kelas apabila guru ataupun wali kelas meminta konseli X untuk menyampaikan pendapat, menjawab soal dipapan tulis yang berkaitan dengan materi pelajaran tanpa konseli $\mathrm{X}$ merasa ragu-ragu dan malu untuk maju. kedepan kelas. Konseli $\mathrm{X}$ juga sudah berani bertanya apabila ada pelajaran yang belum konseli $\mathrm{X}$ mengerti, menerima kelebihan dan kekuranganya, semangat untuk belajar disekolah, mulai berbaur dengan teman-temannya dan belajar untuk tidak sakit hati jika diejek oleh teman-temannya.

\section{Daftar Pustaka}

Arikunto, S. (2010). Prosedur Penelitian Suatu Pendekatan Praktek. Jakarta: Rieneka Cipta. Hasibuan, R. L., \& Wulandari, R. L. H. (2015). Efektivitas Rational Emotive Behavior Therapy (REBT) untuk Meningkatkan Self Esteem pada Siswa SMP Korban Bullying. Jurnal Psikologi, 11(2), 103-110. 
Hurlock, E. B. (2002). Psikologi Perkembangan: Suatu Pendekatan Sepanjang Rentang Kehidupan. Jakarta: Erlangga.

Ikbal, M., \& Nurjannah, N. (2016). Meningkatkan Self Esteem Dengan Menggunakan Pendekatan Rational Emotive Behavior Therapy Pada Peserta Didik Kelas Viii Di Smp Muhammadiyah Jati Agung Lampung Selatan Tahun Pelajaran 2015/2016. Konseli, 3(1), $33-46$.

Prayitno, \& Amti, E. (2009). Dasar-Dasar Bimbingan dan Konseling. Jakarta: Rineka Cipta.

Rakhmat, J. (2005). Psikologi Komunikasi, edisi revisi. Bandung: Remaja Rosdakarya. Bandung: Remaja Rosdakarya.

Sari, E. K. W., \& Soejanto, L. T. (2016). Keefektifan Konseling Kelompok Rebt Untuk Meningkatkan Self Esteem Mahasiswa. Jurnal Konseling Indonesia, 1(2), 101-106.

Syamsu, Y. L. (2007). Psikologi Perkembangan Anak dan remaja. Bandung: Remaja Rosdakarya. 